\title{
Study of Community Based Tourism in the District West Java
}

\author{
Juliana $^{1^{*}}$, Rizaldi Parani ${ }^{2}$, Nova Irene Bernedeta Sitorus ${ }^{3}$, Rudy Pramono ${ }^{4}$, Sandra Maleachi ${ }^{1}$ \\ ${ }^{1}$ Hospitality Management, Pelita Harapan University, Tangerang 15811, Indonesia \\ ${ }^{2}$ Communication Science Department, Pelita Harapan University, Tangerang 15811, Indonesia \\ ${ }^{3}$ Travel Industry Management Department, Pelita Harapan University, Tangerang 15811, Indonesia \\ ${ }^{4}$ Magister of Tourism Department, Pelita Harapan University, Tangerang 15811, Indonesia
}

Corresponding Author Email: Juliana.stpph@uph.edu

https://doi.org/10.18280/ijsdp.160207

Received: 4 January 2021

Accepted: 26 March 2021

\section{Keywords:}

empowerment, community, tourism, tourism village

\begin{abstract}
This study aims to determine on how the concept of community based tourism is applied in several tourist villages in West Bandung Regency. This study uses a qualitative method with a case study concept. Data collection techniques used in the study were observation, in-depth interviews, literature study and documentation. The conclusions of this study are: Cibodas Village has been running and feeling the impact of community-based tourism and can be an example for other tourist villages in West Bandung Regency. The community of Sunten Jaya Village has not been active in managing tourism activity, this village has the potential to develop community-based tourism with serious assistance and support from the government. Cihanjuang Rahayu Village also has good potential to be developed with the concept of community-based tourism but assistance is still needed to be more focused on improving accessibility and tourism support facilities. Rende Village, there are some issues that need to be addressed in this village related to tourism management, community involvement and village managers where previously there was an assistance but it did not work well. This village needs to be considered and actively assisted if it is to be developed into a tourist village.
\end{abstract}

\section{INTRODUCTION}

Community-based tourism is now an alternative to be able to provide community welfare and empowerment for sustainable tourism. After the importance of community participation in village development to become a sustainable tourism destination, it encourages Community Based Tourism. Indonesia is an archipelago that has the potential for biodiversity that has the opportunity to be developed as a tourist attraction. Community based tourism is gaining worldwide prestige as an alternative to mass tourism. This new type of tourism favors contacts with local communities and experimenting with different sensations [1]. Inequality is growing all over the world. Tourism as a major global sector with tremendous growth potential and historical reach is capable of making a substantial contribution to fighting inequality [2].

West Java Province is one of the areas that with a great demand as one of the top lists as a family vacation destination, apart from Bali and Yogyakarta. This is in line with data [3] which shows an increase in visits every year in the last 5 years, namely in 2014 which were visited by 48.894823 people, in 2015 it was visited by 57,401,977 people, in 2016 it was visited by 60.483381 people, in 2017 was visited by $61,682,389$ people, and in 201865.896063 people were visited. In a smaller scope, Bandung Regency in 2016 was ranked first with the highest number of visits in West Java province (6,450,468 people), and dropped to fourth place in 2017 $(3,964,181$ people). The chairman of PHRI said the decline in domestic visits was due to infrastructure development on the
Jakarta-Cikampek toll road, while overseas visits decreased due to a lack of innovation from tourist destinations and competition with other countries in Asia [4] Bandung Regency has natural beauty that attracts visitors for recreation. The high number of visitors is supported by the existence of a tourist village. As noted in the Bandung Regent's Decree number 556.42 / Kop.71-Dispopar / 2011, there are 9 villages with the status of tourism villages, of which 7 are agro-ecotourism and 2 are arts and cultural tourism. The number of tourist visits to West Bandung Regency (KBB) reached 5,847,932 visits in 2018. This figure is based on data collection from the KBB Tourism and Culture Office to 56 tourist attractions [5]. Agus Nurul said the number of visits consisted of 5,814,070 local tourist visits and 33,860 foreign tourist visits. According to [6] his opinion is that community empowerment is a process that not only develops the economic potential of people who are helpless but also seeks to increase their dignity, selfconfidence and self-esteem, as well as to maintain the order of local cultural values. Community empowerment is an effort to strengthen the power of the helpless group. Tourism development is a community-based activity. With the main factors of resources and the uniqueness of the local community, both in the form of physical and non-physical elements (traditions and culture) attached to the community, it is hoped that they can become the main driving force in tourism. To realize a well-run tourism development, the basic thing to do is how to facilitate the broad involvement of local communities in the development process and maximize the social and economic benefits of tourism activities for the local community. The local community has an equally important 
position as a stakeholder in tourism development apart from the government and the tourism industry. According to [7] tourism development is an economically promising market and can be a source of livelihood for people in tourist areas, and is also expected to be the main economic driving force for the village. According to [8] the development of tourism in Indonesia is felt to be more focused on economic and aesthetic values related to the industrial scale, compared to the cultural, social and environmental wisdom values of the Community. In line with this, the government also has not put in place indicators of success in terms of welfare, participation, and satisfaction of the people around the location of tourist objects that are directly related to tourists.

The concept of community empowerment, in tourism development must be directed at several things such as:

1. Increase the capacity, role and community initiatives in tourism development.

2. Improve the position and quality of community involvement / participation.

3 . The increased value of the positive benefits of tourism development for economic welfare.

Tourism development cannot be separated from the resources and uniqueness of local communities, both in the form of physical and non-physical elements which are the main driving elements of tourism activities themselves. Tourism should be viewed as a community-based activity which is manifested in the following ways:

1. As a form of tourism governance which provides opportunities for local communities to control and be actively involved in the management and development of existing tourism.

2. As a form of tourism governance which can provide opportunities for people who are directly involved in tourism ventures and to benefit from existing tourism.

3. As a form of tourism that demands systematic and democratic empowerment and equitable distribution of benefits to disadvantaged communities in destinations.

Community-based tourism is related to the active participation of the local community in existing tourism development. Community participation consists of two perspectives, namely community participation in the decisionmaking process and participation related to the distribution of benefits that will be received by the community from tourism development. Therefore, there are three strategies in community-based tourism development planning, as follows:

1. Involve community members.

2. Local people must receive the benefits of tourism activities.

3. Tourism education for local communities.

According to [9] there are several principles in the concept of community-based tourism, namely:

1. Recognizing, supporting and promoting community ownership in tourism.

2. Involve community members from every stage of tourism development in various aspects.

3. Promote pride in the community concerned.

4. Improve the quality of life.

5. Ensuring environmental sustainability.

6. Protecting the uniqueness and culture of local communities.

7. Developing cross-cultural learning.

8. Respect for cultural differences and human dignity.

9. Distribute profits professionally to members of the public.
10. Contribute a certain percentage of the income earned for community development.

11. Accentuate the authenticity of the community's relationship with the environment.

Currently, Community Based Tourism or community-based tourism is a potential contributor in developing tourism. A concrete example is when tourism is managed by involving the activities of rural communities, the income from tourism activities has a direct impact on the economy of the village community. Villagers can offer residents' houses as homestays. Ernawati et al. [10] argues that to help people develop Community based tourism in a sustainable manner requires a deeper understanding of the changing and growing tourism niche.

West Bandung Regency has 5 tourist villages that are under development. The five tourist villages are Sunten Jaya Village, Lembang District, Cihanjuang Village, Parongpong District, Mukapayung Village, Cililin District, Sinar Jaya Village, Gunung Halu District and Rende Village, Cikalongwetan District. These five tourism villages can serve to promote local wisdom and local tourism development. For the development of this tourism village, the government is preparing a Tourism Village Decree so that it can facilitate the development and development of the five tourist villages. With the formation of a tourist village, it is also expected to improve the community's economy. The management of this tourism village will also be taken over by many tourism awareness groups in each tourist village.

West Bandung Regency has 5 tourist villages that are under development. The five tourism villages are Sunten Jaya Village, Lembang District, Cihanjuang Village, Parongpong District, Mukapayung Village, Cililin District, Sinar Jaya Village, Gunung Halu District and Rende Village, Cikalongwetan District. These five tourism villages can serve to promote local wisdom and local tourism development. For the development of this tourism village, the government is preparing a Tourism Village Decree so that it can facilitate the development and development of the five tourist villages. With the formation of a tourist village, it is also expected to improve the community's economy. The management of this tourism village will also be taken over by many tourism awareness groups in each tourist village. Based on the explanation above, the title for this research is Community Based Tourism Studies in West Bandung Regency.

Based on the explanation above, the researcher is interested in researching how to empower the community in developing a community-based tourism concept in the Tourism Village of West Bandung Regency. The formulation of the problem in this study are:

1. What is the profile of the Tourism Village in West Bandung Regency?

2. How is community-based tourism in the West Bandung Regency Tourism Village?

The purpose of this study is to identify how the profile of the Tourism Village in West Bandung Regency and to identify how community-based tourism management is in the Tourism Village of West Bandung Regency.

This research contributes in identifying tourist attractions and implementing community-based tourism in West Bandung Regency. Thus, it can be used as a foundation in developing tourism villages and the concept of communitybased tourism in West Bandung Regency. The drawback in this study is the length of time to find information in the field due to the current Covid-19 pandemic conditions. 


\section{LITERATURE REVIEW}

\subsection{Community based tourism}

According to the [11] community-based tourism or CBT is an activity that is owned, operated or managed and coordinated at the community or community level. This activity is aimed at the welfare of the community through support for sustainable livelihoods and protecting social traditions and culture in the community. The principles that must be contained in community-based tourism are:

1. Involve and empower communities in determining ownership and management in a transparent manner.

2. Establish partnerships with relevant stakeholders.

3. Obtain an acknowledged position with the relevant authorities.

4. Improve social welfare and maintenance of human dignity.

5. Include a fair and transparent benefit sharing mechanism.

6 . Improve relations with local and regional economies.

7. Respect local culture and traditions.

8. Contribute to nature conservation.

9. Improve the quality of the visitor experience by strengthening the interaction between hosts and visitors.

10. Work towards financial independence.

According to [6] community-based tourism is tourism that involves the community with certainty of benefits obtained by the community through planning assistance to local communities and other groups who have enthusiasm or interest in tourism with tourism management which provides greater opportunities for realizing the welfare of the local community.

Community-based tourism is a tourism where the local community plays a major role in tourism development. Although it focuses on the factor of community involvement as the main actor of development, the roles of the government and private sector are also very much needed in encouraging the success of development in the area. Local communities are considered to be determinants in development and decision making, community involvement is needed both from the planning stage, the implementation stage as well as the potential management and evaluators [12]. Conceptually, the basic principles of community-based tourism are to position the community in tourism development as the main actor, as well as to involve the community's active participation in every activity. So that the community becomes a top priority in receiving benefits to improve welfare. The concept of community-based tourism has been used in carrying out directional actions by tourism development designers, so that in community development they can actively participate in supporting the tourism industry [13].

Community based tourism or community-based tourism according to [9] is a tourism development that is managed and owned by the community with the aim of developing tourism in a sustainable manner and to increase awareness and learning to tourists about the way of life of local communities.

There are several principles in implementing communitybased tourism including: recognize and support and develop community ownership in the tourism industry, involve community members in starting every aspect, developing community pride, developing the quality of life of the community, ensuring environmental sustainability, maintain the unique character and local culture, help develop learning about cultural exchange in the community, respect cultural differences and human dignity, distribute benefits fairly to the community, play a role in determining the percentage of income

According to [14] community-based tourism requires community participation and involvement, especially the local community. Without community involvement, communitybased tourism cannot achieve its goals and objectives. Community-based tourism development can also be interpreted as a development approach that emphasizes the people's economy and community empowerment. Tourism destinations that involve community participation as the core of their development are a reaction to the failure of development carried out by the modernization of the First World to the Third World. In addition, it is also a correction to the creation of tourism products from the Fordism approach (products made in large and homogeneous quantities) towards the postfordist approach (products made in small and varied quantities), as well as to attract quality tourist visits. According to UNWTO, there are five types of communitybased tourism, such as arts and craft tourism, rural tourism, agrotourism, village tourism and ecotourism.

The five types of community-based tourism as described by UNWTO are supported by a statement from [15] that the community participation approach aims to empower and enable people to play an active role in determining decisionmaking and development implementation. Community-based tourism has several characteristics, including: small scale, owned by members / local community groups so as to provide benefits to the community itself, provide employment and local economic opportunities, locations are scattered or not concentrated in a place, activities reflect the character of the local area, promote the preservation of cultural heritage, do not kill industry or other activities and are complementary, offering tourists a quality experience, profitable activities

Community-based tourism development according to [16] has the following characteristics:

1. Community-based tourism finds its rationality in properties and unique characteristics and characteristics that are more unique and organized on a small scale, this type of tourism is basically ecologically safe and does not cause as many negative impacts as those generated by conventional types of tourism

2. Community-based tourism has the opportunity to be better able to develop small-scale tourist objects and attractions and therefore can be managed by local communities and entrepreneurs

3. Community based tourism is closely related and as a consequence of both, where local communities involve themselves in enjoying the benefits of tourism development, and therefore more empowering communities.

The emphasis is on community-based tourism, first of all, not on attractiveness, but on ownership, management, involvement [17] The growth of tourism is increasing so that to develop tourism, a business is needed. Whereas community participation is an important part of tourism development because it allows many stakeholders to build strong political leadership and efforts to build a collective consensus to build community participation; the delegation proposed ideas in developing active community participation [18].

The objectives of community empowerment according to [19] are as follows:

1. To help accelerate the implementation of rural community development projects that are directly related to poverty 
alleviation and fulfill the basic needs of rural communities.

2. To encourage and increase social awareness and concern for the social participation of rural communities in the implementation of rural community development.

3. To increase the capacity of local community institutions to be functionally active in the village community development process.

Apart from being related to social and economic benefits for the community [20], outlines several principles in communitybased development as follows: empowerment of local communities, appreciation and utilization of local wisdom, mobilizing community participation, respect the rights of local communities, pay attention to environmental sustainability

Empowerment must be carried out comprehensively and continuously to get a balance between the government and all aspects ordered. A community empowerment strategy needs to be done because it can see problems that occur in certain areas by involving community participation. Communitybased tourism must pay attention to the absolute involvement of local communities, the requirements for achieving sustainable tourism development Its management must be carried out by local communities whose lives and lives are influenced by development [21] so that it leads to communitybased management systems as actors. main tourism.

Community based tourism is a tourism management model, where local people are directly involved in the management and sustainability of tourism in the area [22] Continuity is a vital issue in policy-making related to management and tourism development [23].

\subsection{Tourism village}

According to Law Number 10 of 2009, a tourist village is a tourist destination or tourist destination that integrates tourist attractions, public facilities, tourism facilities, accessibility which is presented in a structure of community life that integrates with prevailing customs and traditions. According to [24] tourism village is a combination of natural attractions, culture and creativity of the local community, supported by accommodation and other facilities, which can attract tourists to visit. Tourism villages involve villages with all local resources that are owned, managed, and presented to tourists [25]. Thus, developing a tourist village can be an effort to foster potential local entrepreneurship, diversify tourism products, support the economy of the local community, and revitalize local culture [26] Tourism Village according to [27] there are two main concepts in the Tourism Village component, including accommodation. Part of the residence of the local population and / or units that develop on the concept of residents' dwellings and attractions. integrating tourists as active participation, such as courses in dance, language, skills, arts, etc.

According to [28] there are two forms of tourism village according to the process, pattern, and type of management: the structured type and open type.

The types of tourists who come to the tourist village according to [28] are: domestic tourists, foreign tourists.

\subsection{Previous research}

According to [29] the government has an important role in the development of community based tourism in Guyana. Community based tourism should be considered as one of the tools aimed at the development and economic growth of a country. In driving this community based tourism program, the one that plays the most roles is the community and the government to facilitate it. Thus, the benefits obtained can make the community prosperous. According to [30] based on this research it is certain that a community based tourism is not only the community itself but also a legal and normative framework that can be implemented. Local cooperation, trust, networks and partnerships with various stakeholders are also factors that support community based-tourism. According to [31] sustainability in rural tourism which focuses on indigenous communities and has provided great benefits. This study also discusses the creation of resourced based applications that are useful for tourism development. The resources and capabilities that exist in the community rely on the strategy and movement of the organization so as to produce an advantage for rural tourism. In this study what distinguished it from several previous studies are:

1. This study focuses on 4 tourist villages with different characters

2. This study looks at how the community is involved in developing tourism in the village.

3. The results will show the identification of tourist attraction in each villages and the condition of community based tourism.

\section{METHOD}

This research is a type of qualitative research with a case study approach. According to [32] qualitative research is research that emphasizes understanding the problems in social life based on reality in natural setting conditions.

The design used in this research is a case study. A case study is a study that explores a case in depth, collected complete information that is used in various data collection procedures based on a predetermined time. This case can be in the form of events, activities, processes, and programs [33].

There are several steps in designing a case study, namely: determining and describing research questions, selecting and determining research designs and instruments, determining data collection techniques and carrying out data collection activities, making data analysis, and preparing the final research report. In this study, data sources were divided into 2 parts, namely primary data and secondary data. Primary data is data obtained directly by data collectors. Primary data is obtained from several key informants in West Bandung Regency including West Bandung tourism office staff, Village Heads and Village Secretaries. Meanwhile, secondary data is data obtained indirectly, either through other parties or through documents. In this study, secondary data is data obtained through literature study, the internet and other sources related to research [34]. Data collection techniques used in the study were observation, in depth interviews, literature study and documentation. Observation is a data collection technique by making direct observations to the research location in order to obtain clear and valid information related to the research topic. In this study, observations were done by visiting several tourist villages directly in West Bandung Regency to see and identify the attractions possessed by these tourist villages. By doing these observations, the researcher found a variety of tourist attractions in each village in West Bandung Regency. With the results of the identification of this tourist attraction, it can help researchers to connect it with the concept of community based tourism. An in-depth interview is a question and answer 
activity carried out directly with key informants who master the research topic. The interview guide is used which contains various questions about the conditions of each tourism village and community based tourism. In-depth interviews were conducted in 4 tourist villages in West Bandung Regency with several key informants representing each tourist village. From Cibodas Tourism Village, there are 2 key informants, namely tourism village managers and homestay managers. For Sunten Jaya Tourism Village, there are 5 key informants, one representative of the village office and 4 others to provide information about tourist attractions and village community activities. For Cihanjuang Rahayu tourism village, there are 3 key informations, namely 1 person representing the tourism village and its management, 1 person representing the village office and 1 person representing the tourist attraction manager. Whereas the last one is Rende tourism village which has 3 key informants, namely the village head, the village secretary and the community who know the condition of Rende Tourism Village.

Literature study is a data collection technique using several relevant and scientific book references according to the research topic. Documentation is a data collection technique in the form of records of past events. Documentation can be in the form of writing, pictures, or monumental works. Documentation can also take the form of daily notes, history, biographies, regulations and policies and can be in the form of photos, drawings, sketches and others. The documentation obtained from the field is the profile about the village, conditions of tourist attractions and others.

The technique of determining key informants in this study used purposive sampling technique where the key informants selected were informants who mastered the research topic.

Data analysis is a continuous process that requires continuous reflection on data by asking analytical questions and writing short notes during research [33] The data analysis technique used in this research is descriptive analysis, which describes actual events based on the data and facts contained in the research object at the time of the research. In addition to data analysis, it also uses categorization techniques, namely compiling categories from a set of findings data arranged based on thoughts, intuition, opinions or certain criteria.

Data analysis is the process of organizing and sorting data about patterns, categories, basic unit descriptions so that themes can be found, and working hypotheses can be formulated according to suggestions from the data collected. This means that data analysis intends to first compile data, namely data collected, namely primary data and secondary data such as interviews, official documents, literature, field notes, documentation, activity reports and other data then compiled, after which the researcher will compile them. processing and analyzing data using qualitative descriptive analysis, which produces the final analysis in the form of words, sentences, terms, pictures and subject behavior, without using quantitative techniques that use numbers or nominal data. The data analysis method of this research will be carried out by the data triangulation process. The accuracy of the data can be determined using triangulation. The validity test is also explained according to [34] which includes testing, credibility (verbal validity), transferability (external validity), dependability (reliability), and confirmability (objectivity).

\section{ANALYSIS AND FINDINGS}

West Bandung has a high level of tourist visits to all West
Bandung tourist attractions in 2019 , amounting to $6,207,428$ tourists and has decreased in 2020 to $1,161,664$ tourists due to the Covid 19 Pandemic. In 2019 the number of visits to tourist accommodation in the Regency West Bandung totaling 70,868 visits and has decreased to 38,187 visits in 2020 . At the beginning of the study, secondary data obtained states that West Bandung Regency has 5 tourist villages that are under development. The five tourism villages are Sunten Jaya Village, Lembang District, Cihanjuang Village, Parongpong District, Mukapayung Village, Cililin District, Sinar Jaya Village, Gunung Halu District and Rende Village, Cikalongwetan District. However, when the data search process took place at the West Bandung Regency Tourism Office, data was obtained that there were several tourist villages in West Bandung Regency as follows: Lembang District: Suntenjaya Tourism Village, Cibodas Tourism Village, Cikidang Tourism Village, Pagerwangi Tourism Village, Karyawangi Tourism Village, Parongpong Subdistrict: Cihideung Tourism Village, Cihanjuang Rahayu Tourism Village, Cisarua District: Kertawangi Tourism Village, Cipatat District: Mt. Masigit Tourism Village, Gunung Halu District: Gunung Halu Tourism Village, Sirnajaya Tourism Village, Cipendeuy District: Bojong Mekar Tourism Village, Margalaksana Tourism Village, Cikalongwetan District: Cipada 1 Tourism Village, Rende Tourism Village, Cililin District: Mukapayung Tourism Village of the 16 tourist villages described by the key informants, the researcher took 4 tourist villages which were the objects of research, namely Cibodas Tourism Village, Sunten Jaya Tourism Village and Cihanjuang Rahayu Tourism Village. The reason the researchers chose the four villages was due to the distance between villages that were far apart. The four villages also represent the conditions of a well-managed tourism village and a tourist village that only has potential but has not been managed properly. Cibodas tourism village represents a well-managed tourist village. Meanwhile, Sunten Jaya and Cihanjuang Rahayu Tourism Villages represent tourism villages that have extraordinary tourism potential, both natural and cultural tourism, but have not been managed properly. Rende tourism village represents a tourism village that has tourism potential and has the opportunity to develop (indicated by the Regent's Decree regarding a tourism village that has been received by Rende tourism village) but there has been no significant development to date in managing a tourist village. The tourism products in Cibodas Village consist of nature tourism and homestays. Many tourism products have been well managed such as The Lodge, Bougenville and several other attractions. This travel product. Although almost $80 \%$ of the area in the village is used for plantations and livestock, tourism in Cibodas Village has developed. The tourism products in Sunten Jaya Village consist of natural and cultural tourism. Nature tourism is still only potential, not managed professionally. Natural attractions in this village are Curug Luhur / Batu Ampar, Curug Lalay, Pasir Angling, Taman Bincarung, Vegetable plantations that can be enjoyed with a traditional gondola (Sasak Apung Padjajaran), etc. Cultural tourism found in this village is the stone bell which has a myth. There is also a coffee plantation that is still managed professionally by the community, namely Eka Harapan Coffee Plantation. In Cihanjuang Rahayu Tourism Village, there are many tourist attractions such as Ciwangun Indah Camp, Curug Bebrek, Curug Penganten, and the Singapore Valley. Among the several tourist attractions, only Ciwangun Indah Camp which has been managed 
professionally. The Singapore Valley has a very good view and has the potential to be developed and attract many tourists. However, access and facilities are still very minimal and traditional so that they are not yet open to tourists. There are no professional guides and a very steep road to this place. Only 1 attraction that has been managed professionally. Finally, Rende Village, in terms of natural tourist attraction, nothing stands out. However, the district head's decree requires Rende Village to be able to highlight its tourism potential. However, there is one spiritual or religious tourism in the Tomb of Eyang Rende with minimal management from the tourism office, nothing has been touched. For religious tourism, many visit to see the graves of their predecessors. There is a homestay and gate but they are no longer maintained. There are 3 huts but that is also nothing to do. There are natural attractions such as sand dunes to be developed as flying fox. There is Parajikpuhun, a tradition of rice harvesting, but it doesn't work as a tourist attraction either. All tourism activities in the village are just planning. Community-based tourism development according to [16] has the following characteristics:

1. Community-based tourism finds its rationality in properties and unique characteristics as well as more unique characters and is organized on a small scale. This type of tourism is basically ecologically safe and does not cause as many negative impacts as that generated by conventional types of tourism. Based on these characteristics, among the four tourism villages discussed, Cibodas Tourism Village already has the character and uniqueness of a tourist village that is managed and does not damage the environment. Sunten Jaya Tourism Village also has a unique village character, namely there are many natural and cultural tourism potentials whose activities can be a support in developing a tourist village. The daily activities carried out by the community such as gardening and raising livestock can also be an attraction in developing the Sunten Jaya Tourism Village. Cihanjuang Rahayu Tourism Village has a unique natural attraction and can be an attraction in developing a tourist village but the accessibility and available facilities are not suitable for tourists to visit. Rende Tourism Village is also different from the other three villages, this village does not have natural attractions as beautiful as Cibodas Village, Sunten Jaya and Cihanjuang Rahayu Village. Rende Village only has religious-based tourist attractions, namely several ancestral graves that are visited by many people on certain religious ceremony days. Rende Village was once given the opportunity to build a tourist village and already has a Regent's Decree, but there has been no development to date. Several homestays that have been built have been damaged and no one manages them. This shows that there is no seriousness between the village manager and the community in building the Rende Tourism Village.

2. Community-based tourism has the opportunity to be more capable of developing small-scale tourist objects and attractions and therefore can be managed by local communities and entrepreneurs. Based on data obtained from key informants, Cibodas Village has used the opportunities available in developing tourism in the village. There are attractions such as The Lodge which already has many visitors until now. Cibodas Tourism Village also already has several homestays that are professionally managed and are in great demand by tourists until before the Covid 19 pandemic. Due to the Covid 19 pandemic, this homestay is no longer allowed to accept tourists who stay overnight because it is very risky of bringing the virus to the families that run the homestay. Cibodas Tourism Village as a whole has managed tourism in the village well. The community has also been involved and has felt the benefits of tourism in this village. The POKDARWIS community is also active in helping the development of this tourist village. In contrast to Sunten Jaya Village, Cihanjuang Rahayu Village and Rende Village, which have not been able to provide benefits and prosperity to the community through tourism. In Sunten Jaya Tourism Village, only a few parties have experienced the benefits of tourism, such as making traditional coffee tours, making milk candy with traditional concepts as well and farming vegetables and fruits. Tourism in Sunten Jaya Village needs to be seriously and actively considered and accompanied so that it can provide benefits to the community. Tourism activating communities also need to be activated in Sunten Jaya Village. For Cihanjuang Rahayu Tourism Village, the community has not been able to realize the benefits of tourism so they still only focus on gardening watercress vegetables for export to cities in West Java and Jakarta as well as to Singapore. The drivers of tourism in this village are still only a few local people, but there is no official community that can actively drive tourism in this village. Rende Village is the most in need of attention to develop its tourism. Special assistance is needed for this village because there are tourism potentials previously programmed by several universities in this village such as spices and homestays as well as several water tourism programs which are almost established but are constrained by costs. This village also no longer carries out tourism activities for the community or tourists except for religious tours to ancestral graves. This village also does not have a tourist drive. Community-based tourism is closely related and as a consequence of both, where local communities involve themselves in enjoying the benefits of tourism development, and therefore more empowering communities. Of the four tourism villages discussed, Cibodas Tourism Village is a village that can be used as an example in developing community-based tourism. The local community or community is empowered to manage tourist attractions and homestays in Cibodas Village. The community feels the benefits of tourism. The community is involved in managing a homestay and winning national level awards in homestay management beating out one of the homestays in Bali. People are also being recruited as employees at several tourist attractions such as The Lodge Maribaya.

For Sunten Jaya Tourism Village, there are still few people involved in tourism activities, such as in managing coffee tours with a traditional concept and some participation in managing typical souvenirs of Sunten Jaya Village. Many people still focus on the plantation and livestock sector. Cihanjuang Rahayu Tourism Village, the community involved is only in Ciwangun Indah Camp as employees. However, as a whole the community still focuses on vegetable plantations for the products to be exported to Singapore and several supermarkets in Bandung or Jakarta. Rende Tourism Village No community participation. The community really hopes that tourism will run, so that the community can be involved. There is a lot of planning but no support so that the community cannot take part. Pokdarwis has also been formed and BIMTEK was held in 2014 but there has been no continuation either.

The community-based tourism conditions of the four tourist villages are: Cibodas Village, many people have been involved in various tourism management activities both tourist attractions and homestay management. Pokdarwis has been formed and actively takes part in managing tourism in Cibodas 
Village. This village has been running and feeling the impact of community-based tourism and can be an example for other tourist villages in West Bandung Regency in implementing the concept of community-based tourism. Sunten Jaya Village has extraordinary natural and cultural tourism potential but the community has not been active in managing tourism in Sunten Jaya Village. The community is still focused on gardening and raising livestock. The community is only actively involved in making souvenirs and traditional coffee tourism. This village has the potential to develop community-based tourism with serious assistance and support from the government. For Cihanjuang Rahayu Tourism Village, the tourist attraction is the Singapore valley and several waterfalls but there is no management and access and facilities that are not feasible. Only Ciwangun Indah Camp has good management but only a few communities are empowered. This village also has good potential to be developed with the concept of communitybased tourism. Not only assistance is needed but also must be more focused on improving accessibility and tourism support facilities. Desa Wisata Rende, tourism planning has not been continued by the government for a long time so that the community also cannot get involved. In a sense, there is a lot that needs to be addressed in this village related to tourism management, community involvement and village managers where previously there was assistance but it did not work. This village needs to be actively considered and assisted if it is to be developed into a tourist village.

In managing tourism, the four villages have several obstacles such as: Cibodas Village is good at managing a tourist village and the village community has also actively participated in developing tourism in Cibodas Village, but COVID 19 is an obstacle so that many people cannot carry out their work because of the many tourist attractions and homestays that are closed and have limited visits. In Sunten Jaya Village, the people who are still focused on plantation and livestock activities have made the tourism aspect not run well. The existing tourist attraction is also lacking in management due to lack of financial support and people who do not have tourism mindedness. In Cihanjuang Rahayu Village, the natural tourist attraction of the beautiful Singapore Valley cannot be managed professionally due to inadequate accessibility and facilities due to the lack of funds that can be used. The existing waterfalls are also not well managed. As for the Tourism Village of Rende, the Regent's Decree on tourism villages could not be implemented because there was no continuation from related agencies. Several tourist attractions already exist but lack of capital. The entire attraction is not well managed.

\section{CONCLUSIONS}

The conclusions of this study are:

1. Tourism products in Cibodas Village consist of nature tourism and homestays. Many tourism products have been well managed such as The Lodge, Bougenville and several other attractions. This travel product. Although almost $80 \%$ of the area in the village is used for plantations and livestock, tourism in Cibodas Village has developed. The tourism products in Sunten Jaya Village consist of natural and cultural tourism. Nature tourism is still only potential, not managed professionally. Natural attractions in this village are Curug Luhur / Batu Ampar, Curug Lalay, Pasir Angling, Taman Bincarung, Vegetable plantations that can be enjoyed with a traditional gondola (Sasak Apung Padjajaran), etc. Cultural tourism found in this village is the stone bell which has a myth. There is also a coffee plantation that is still managed professionally by the community, namely Eka Harapan Coffee Plantation. In Cihanjuang Rahayu Tourism Village, there are many tourist attractions such as Ciwangun Indah Camp, Curug Bebrek, Curug Penganten, and the Singapore Valley. Among the several tourist attractions, only Ciwangun Indah Camp which has been managed professionally. The Singapore Valley has a very good view and has the potential to be developed and attract many tourists. However, access and facilities are still very minimal and traditional so that they are not yet open to tourists. There are no professional guides and a very steep road to this place. Only 1 attraction that has been managed professionally. Finally, Rende Village, in terms of natural tourist attraction, nothing stands out. However, the district head's decree requires Rende Village to be able to highlight its tourism potential. However, there is one spiritual or religious tourism in the Tomb of Eyang Rende with minimal management from the tourism office, nothing has been touched. For religious tourism, many visit to see the graves of their predecessors. There is a homestay and gate but they are no longer maintained. There are 3 huts but that is also nothing to do. There are natural attractions such as sand dunes to be developed as flying fox. There is Parajikpuhun, a tradition of rice harvesting, but it doesn't work as a tourist attraction either. All tourism activities in the village are just planning.

The conditions of community-based tourism from the four tourism villages are: Cibodas Village, many people have been involved in various tourism management activities, both tourist attractions and homestay management. Pokdarwis has been formed and actively takes part in managing tourism in Cibodas Village. This village has been running and feeling the impact of community-based tourism and can be an example for other tourist villages in West Bandung Regency in implementing the concept of community-based tourism. Sunten Jaya Village has extraordinary natural and cultural tourism potential but the community has not been active in managing tourism in Sunten Jaya Village. The community is still focused on gardening and raising livestock. The community is only actively involved in making souvenirs and traditional coffee tourism. This village has the potential to develop community-based tourism with serious assistance and support from the government. For Cihanjuang Rahayu Tourism Village, the tourist attraction is the Singapore valley and several waterfalls but there is no management and access and facilities that are not feasible. Only Ciwangun Indah Camp has good management but only a few communities are empowered. This village also has good potential to be developed with the concept of community-based tourism. Not only assistance is needed but also must be more focused on improving accessibility and tourism support facilities. Desa Wisata Rende, tourism planning has not been continued by the government for a long time so that the community also cannot get involved. In a sense, there is a lot that needs to be addressed in this village related to tourism management, community involvement and village managers where previously there was assistance but it did not work. This village needs to be actively considered and assisted if it is to be developed into a tourist village.

The suggestions given for this research are:

1. Cibodas Village: COVID 19 is an obstacle so that many people cannot carry out their jobs because many tourist attractions and homestays are closed and their visits are limited. 
Cibodas Village should apply health protocols to start tourism activities in this village and be even more active in marketing online tourist attractions and homestays to deal with the situation after the pandemic later.

2. In Sunten Jaya Village, the people who are still focused on plantation and livestock activities make the tourism aspect not going well. The existing tourist attraction is also lacking in management due to lack of financial support and people who do not have tourism mindedness. The government can provide more socialization in implementing community-based tourism and form tourism drivers in Sunten Jaya Village.

3. In Cihanjuang Rahayu Village, the natural tourist attraction of the beautiful Singapore Valley cannot be managed professionally due to inadequate accessibility and facilities due to the absence of funds that can be used. The existing waterfalls are also not well managed. Accessibility and facilities must be improved and suitable for visitors. The community must also begin to be assisted in applying the concept of community-based tourism.

4. Rende tourism village, the Regent's Decree regarding tourism villages cannot be implemented because there is no continuation from the related agencies. Several tourist attractions already exist but lack of capital. The entire attraction is not well managed. This village should be reviewed for its tourism potential and assistance is needed for the application of the concept of community-based tourism

\section{REFERENCES}

[1] López-Guzmán, T., Sánchez-Cañizares, S., Pavón, V. (2011). Community-based tourism in developing countries: A case study. Tourismos, 6(1): 69-84.

[2] Giampiccoli, A. (2020). A conceptual justification and a strategy to advance community-based tourism development. European Journal of Tourism Research, 25: 2503-2503.

[3] BPS, Jumlah Kunjungan Wisatawan Bandung, 2019.

[4] Halim, H. The Worst Tourist Drop in Bandung. Media Pikiran Rakyat. www.pikiranrakyat.com/jawa barat, 2017.

[5] Mutaqin Imam, A. Kunjungan Wisatawan ke KBB Capai 5,8 Juta, Miliki Ratusan Destinasi Wisata https://www.pasundanekspres.co/jabar/bandung/kunjun gan-wisatawan-ke-kbb-capai-58-juta-miliki-ratusandestinasi-

wisata/\#: :text=NGAMPRAH\%2DJumlah\%20angka\% 20kunjungan\%20wisatawan,KBB," $\quad$ PASUNDAN EKSPRES, 2019.

[6] Sunaryo, B. (2013). Kebijakan pembangunan destinasi pariwisata: konsep dan aplikasinya di Indonesia (No. 1). Penerbit Gava Media Kebijakan Pembangunan Destinasi Pariwisata: Konsep dan Aplikasinya di Indonesia.

[7] Nur, I. (2018). Implications of Tourism Village Development for Improving the Economy of Local Communities (Study in Pao Village). In National Seminar and Call for Paper Management, Accounting and Banking. https://jbhost.org/jbhost/index.php/jbhost/article/view/1 85

[8] Haryanto, T.J. (2014). Ecotourism development model in supporting regional economic independence (Case Study of DIY Province). Kawistara, 4(2): 271-286.
[9] Suansri, P. (2003). Community Based Tourism Handbook. Bangkok: Responsible Ecological Social Tour-REST.

[10] Ernawati, N.M., Sanders, D., Dowling, R. (2017). Hostguest orientations of community-based tourism products: A case study in Bali, Indonesia. International Journal of Tourism Research, 19(3): 367-382. https://doi.org/10.1002/jtr.2119

[11] Asean Community Based Tourism Standard, Asean Community Based. Jakarta: ASEAN Secretariat, 2016. https://www.asean.org/storage/2012/05/ASEANCommunity-Based-Tourism-Standard.pdf.

[12] Azni, U.S., Alfitri, A. (2020). The implementation of community based tourism model in the development of the Semambu Island tourism village, Ogan Ilir Regency, South Sumatra. Simulacra, 3(1): 109-120. https://doi.org/10.21107/sml.v3i1.6915

[13] Hermantoro, H. (2011). Creative-based tourism: dari wisata rekreatif menuju wisata krestif. Aditri.

[14] Prasiasa, D.P.O. (2013). Destinasi pariwisata berbasis masyarakat. Jakarta: Salemba Humanika, 2013. https://core.ac.uk/download/pdf/290095422.pdf

[15] Erawan, I.N. (2003). Menuju Pembangunan Pariwisata Bali yang Berkelanjutan. In Makalah pada Seminar Penilaian Dampak Krisis dan Koordinasi Respon Atas Bom Bali Kerja sama UNDP, USAID, dan World Bank, Denpasar, 20. https://doi.org/10.26905/jpp.v4i2.2705

[16] Nasikun, Globalisasi dan Paradigma Baru Pembangunan Pariwisata Berbasis Komunitas. Penguasaan Ekowisata. Yogyakarta: Fakultas Kehutanan UGM dan Pustaka Pelajar, 2000. https://jbhost.org/jbhost/index.php/jbhost/article/view/1 73.

[17] Singh, T.V. (2012). Critical debates in tourism, 57. Channel View Publications.

[18] Kamarudin, K.H. (2013). Local stakeholders participation in developing sustainable community based rural tourism (CBRT): the case of three villages in the East Coast of Malaysia. In International Conference on Tourism Development, 33-40. https://www.academia.edu/3318399.

[19] Jamaludin., Sosiologi Pedesaan. Bandung: CV PUSTAKA SETIA, 2015

[20] Wearing, S., McDonald, M. (2002). The development of community-based tourism: Re-thinking the relationship between tour operators and development agents as intermediaries in rural and isolated area communities. Journal of Sustainable Tourism, 10(3): 191-206. https://doi.org/10.1080/09669580208667162

[21] Pitana, I., Diarta, I. (2009). Pengantar Ilmu Pariwisata. Yogyakarta: Penerbit Andi.

[22] Nair, V., Hussain, K., Chiun, L.M., Ragavan, M.N.A., Lo, M.C., Ragavan, N.A. (2015). Benchmarking innovations and new practices in rural tourism development. Worldwide Hospitality and Tourism Themes, 7(5): 530534., https://doi.org/10.1108/whatt06-2015-0030

[23] Hounnaklang, S. (2016). Concepts, issues and the effectiveness of alternative tourism management in thailand: a case study of plai pong pang homestay, amphoe ampawa, samut songkram province. International Journal of Arts \& Sciences, 9(3): 337.

[24] Amir, A., Sukarno, T.D., Rahmawati, F. (2020). Identifikasi potensi dan status pengembangan desa wisata di kabupaten lombok tengah, nusa tenggara barat. 
Journal of Regional and Rural Development Planning (Jurnal Perencanaan Pembangunan Wilayah Dan Perdesaan), 4(2): 84-98. https://doi.org/10.29244/jp2wd.2020.4.2.84-98

[25] Herawati, A., Purwaningsih, A., Handharko, Y.D. (2018). Promoting village tourism through the development of information systems. Review of Integrative Business and Economics Research, 7: 221-236.

[26] Santhyasa, I.K.G. (2016). Kearifan Lokal Dalam Perencanaan dan Pengembangan Spasial Desa Wisata di Bali. In Seminar Nasional Agama, Adat, Seni dan Sejarah di Zaman Milenial.

[27] Wihasta, C.R., Prakoso, H.B.S. (2012). Perkembangan desa wisata kembang arum dan dampaknya terhadap kondisi sosial ekonomi masyarakat donokerto kecamatan turi. Jurnal Bumi Indonesia, 1(1).

[28] Hadwijoyo, S.S. (2012). Perencanaan Pariwisata Pedesaan Berbasis Masyarakat. Yogyakarta: Graha Ilmu.

[29] Connelly, A., Sam, S. (2018). How can policy assist the development of community-based tourism in Guyana by 2025 and beyond? Worldwide Hospitality and Tourism
Themes, 10(5):

$555-568$.

https://doi.org/10.1108/WHATT-05-2018-0032

[30] Nagy, K.X.H., Segui, A.E. (2020). Experiences of community-based tourism in Romania: Chances and challenges. Journal of Tourism Analysis: Revista de Análisis Turístico. 27(2): 143-163. https://doi.org/10.1108/JTA-08-2019-0033

[31] Artal-Tur, A., Briones-Peñalver, A.J., Bernal-Conesa, J.A., Martínez-Salgado, O. (2019). Rural community tourism and sustainable advantages in Nicaragua. International Journal of Contemporary Hospitality Management, $31(6)$ : 2232-2252. https://doi.org/10.1108/IJCHM-05-2018-0429

[32] Sugiarto, D., Hendratono, T., Sudibyo, Metodologi Penelitian Hospitaliti dan Pariwisata. Tangerang: PT. Matana Publishing Utama, 2015. https://doi.org/10.13140/RG.2.1.3537.8083

[33] Creswell, J.W. (2014). Research Design: Qualitative, Quantitative, and Mixed Methods Approaches. Thousand Oaks, CA: SAGE Publications.

[34] Sugiyono, Metode Penelitian Kuantitatif,Kualitatif,dan R\&D. (2016). 